\title{
Reducing Broadband Shortwave Radiometer Calibration-Bias Caused by Longwave Irradiance in the Reference Direct Beam
}

\author{
Ibrahim Reda, Afshin Andreas, Mike Dooraghi, Manajit Sengupta, Aron Habte, Mark Kutchenreiter \\ National Renewable Energy Laboratory, Golden, USA \\ Email: Ibrahim.reda@nrel.gov
}

How to cite this paper: Reda, I., Andreas, A., Dooraghi, M., Sengupta, M., Habte, A. and Kutchenreiter, M. (2017) Reducing Broadband Shortwave Radiometer Calibration-Bias Caused by Longwave Irradiance in the Reference Direct Beam. Atmospheric and Climate Sciences, 7, 36-47.

http://dx.doi.org/10.4236/acs.2017.71004

Received: October 21, 2016

Accepted: January 10, 2017

Published: January 13, 2017

Copyright $\odot 2017$ by authors and Scientific Research Publishing Inc. This work is licensed under the Creative Commons Attribution International License (CC BY 4.0).

http://creativecommons.org/licenses/by/4.0/

(c) (i) Open Access

\begin{abstract}
Shortwave radiometers such as pyranometers, pyrheliometers, and photovoltaic cells are calibrated with traceability to consensus reference, maintained by Absolute Cavity Radiometers (ACRs). The ACR is an open cavity with no window that measures the extended broadband spectrum of the terrestrial direct solar beam irradiance, unlike shortwave radiometers that cover a limited range of the spectrum. The difference between the two spectral ranges may lead to calibration bias that can exceed $1 \%$. This article describes a method to reduce the calibration bias resulting from using broadband ACRs to calibrate shortwave radiometers by using an ACR with Schott glass window to measure the reference broadband shortwave irradiance in the terrestrial direct solar beam from $0.3 \mu \mathrm{m}$ to $3 \mu \mathrm{m}$. Reducing the calibration bias will result in lowering the historical solar irradiance by at least $0.9 \%$. The published results in this article might raise the awareness of the calibration discrepancy to the users of such radiometers, and open a discussion within the solar and atmospheric science community to define their expectation from such radiometers to the radiometers' manufacturers and calibration providers.
\end{abstract}

\section{Keywords}

Pyranometer, Pyrheliometer, Calibration, Absolute Cavity Pyrheliometer, Photovoltaic Cells, Shortwave

\section{Introduction}

Shortwave radiometers such as pyranometers, pyrheliometers, and photovoltaic cells are calibrated with traceability to the World Radiometric Reference (WRR) (ISO, 1990) [1]. Photovoltaic cells have two traceability chains: the solar simulator method is traceable through a standard lamp to the National Institute of Standards and Technology (NIST) or other National Metrology Institute (NMI) while the solar irradiance method 
is traceable to the WRR [2]. The WRR is maintained by six Absolute Cavity Radiometers (ACR) that form the World Standard Group (WSG), which are located at the Physikalisch-Meteorologisches Observatorium in Davos, Switzerland [3]. The ACR is an open cavity with no windows and was developed to measure the extended broadband spectrum of the terrestrial direct solar beam irradiance that extends beyond the ultraviolet and infrared bands (i.e., below $0.2 \mu \mathrm{m}$ and above $50 \mu \mathrm{m}$, respectively). On the other hand, pyranometers and pyrheliometers measure broadband shortwave irradiance from approximately $0.3 \mu \mathrm{m}$ to $3 \mu \mathrm{m}$ [4] [5] and the silicon-based photovoltaic cells are limited to the spectral range of approximately $0.3 \mu \mathrm{m}$ to $1 \mu \mathrm{m}$. The broadband spectral mismatch of the ACR versus the shortwave radiometers might result in a larger than $1 \%$ bias in the radiometers' calibration methods, as shown in Reda, et al. 2015 [6]. The method described in Reda, et al., 2015 summarizes using two pyrgeometers: one shaded with a Schott glass shading mechanism to block the spectral range greater than $3 \mu \mathrm{m}$ from the direct solar beam, and the other unshaded with spectral range from approximately $3 \mu \mathrm{m}$ to $50 \mu \mathrm{m}$. The Schott glass shading mechanism is used for broadband shortwave radiometers' dome to transmit spectral range from $0.3 \mu \mathrm{m}$ to $3 \mu \mathrm{m}$, per manufacturer design. The reference broadband longwave irradiance in the direct solar beam $\left(W_{L W}\right)$ is then calculated by subtracting the irradiance measured by the shaded pyrgeometer from that measured by the unshaded pyrgeometer.

As will be described in section 2 below, the reference broadband shortwave irradiance $\left(W_{S W}\right)$ is calculated by subtracting the measured reference $W_{L W}$ from the broadband irradiance $\left(W_{B B}\right)$, measured by broadband $\mathrm{ACR}\left(\mathrm{ACR}_{\mathrm{BB}}\right)$ (i.e. $\left.W_{S W}=W_{B B}-W_{L W}\right)$. The reference $W_{S W}$ is then used to calibrate an ACR with Schott glass window $\left(\mathrm{ACR}_{\mathrm{SW}}\right)$, which is then used to calibrate a set of shortwave radiometers. The difference between using $\mathrm{ACR}_{\mathrm{BB}}$ and $\mathrm{ACR}_{\mathrm{SW}}$ to calibrate the radiometers is shown in Section 3 below.

\section{Calibration Procedure}

The shaded and unshaded pyrgeometers, the two $A C R s\left(\mathrm{ACR}_{\mathrm{BB}}\right.$ and $\left.A C R_{\mathrm{SW}}\right)$, and fiveshortwave radiometers, two thermopile pyrheliometers (Eppley Laboratory, Inc., model NIP and Kipp and Zonen model CHP1), two thermopile pyranometers (Eppley Laboratory, Inc., model PSP and Kipp and Zonen model CMP22), and one photodiode pyranometer (Kipp and Zonen model SP Lite2), were set up outdoors at the National Renewable Energy Laboratory's (NREL) Solar Radiation Research Laboratory (SRRL), which is at an elevation of 1828.8 meters above sea level. Data was collected simultaneously from all radiometers under clear sky conditions every 30 seconds, from June 15 to June 18, 2016. The following subsections describe the calibration of the $\mathrm{ACR}_{\mathrm{SW}}$. The $\mathrm{ACR}_{\mathrm{BB}}$ was calibrated with traceability to WRR during NREL Pyrheliometer Comparisons, NPC-2014 [7]. The same outdoor dataset was used to calibrate the shortwave radiometers; their responsivity was calculated using the $\mathrm{ACR}_{\mathrm{BB}}$, then re-calculated using the $\mathrm{ACR}_{\mathrm{SW}}$. The calibration results of the shortwave radiometers by using $\mathrm{ACR}_{\mathrm{BB}}$ and $\mathrm{ACR}_{\mathrm{SW}}$ are compared to show the bias between the two calibration methods.

\subsection{ACR sw $_{\text {Calibration }}$}

Figure 1 show the shaded and unshaded pyrgeometers set up, which was used to 


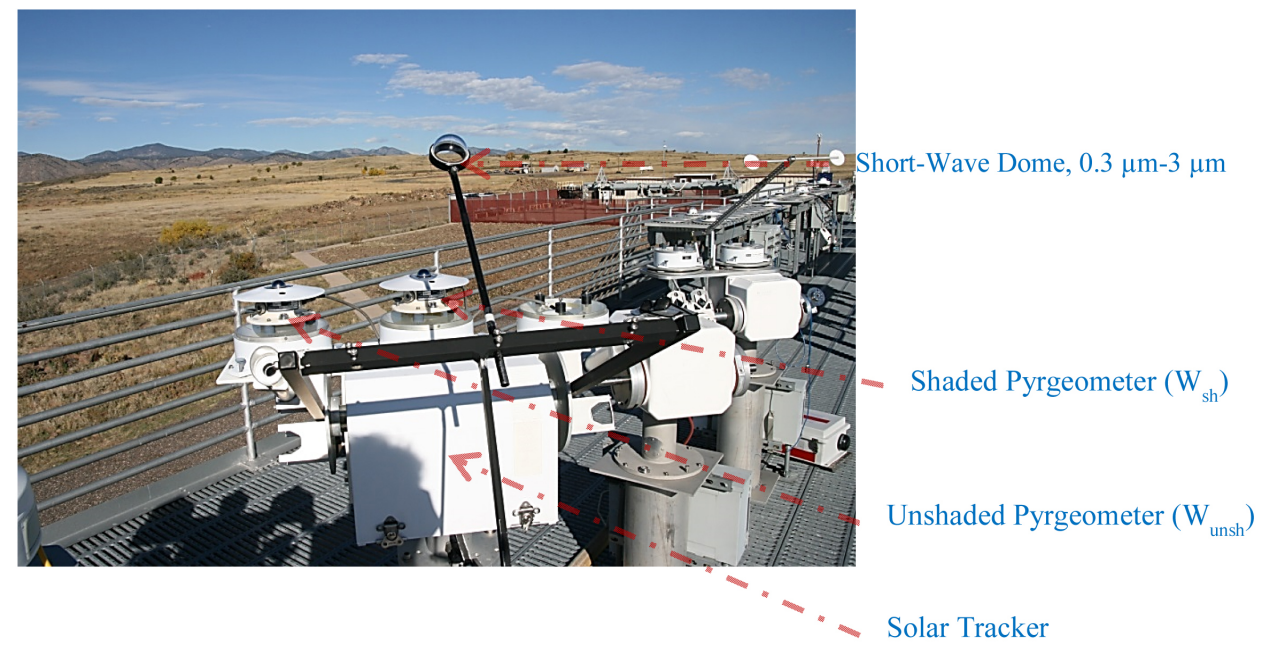

Figure 1. Set up of shaded and unshaded pyrgeometers to measure the longwave irradiance in solar beams.

measure the reference longwave irradiance in the solar beam $\left(W_{L W}\right)$ as:

$$
W_{L W}=\frac{W_{u n s h}-W_{S h}}{\cos \Theta}
$$

where,

- $W_{\text {unsh }}$ is the longwave irradiance measured by the unshaded pyrgeometer $\left(\mathrm{W} \cdot \mathrm{m}^{-2}\right)$

- $\quad W_{s h}$ is the longwave irradiance measured by the shaded pyrgeometer with the Schott glass shading mechanism, see Figure $1\left(\mathrm{~W} \cdot \mathrm{m}^{-2}\right)$

- $\Theta$ is the solar zenith angle $\left({ }^{\circ}\right)$.

Detailed derivation of the equation is presented in Reda et al., 2015. Figure 2 shows the measured reference $W_{L W}$ varies from $3 \mathrm{~W} \cdot \mathrm{m}^{-2}$ to $12 \mathrm{~W} \cdot \mathrm{m}^{-2}$ due to time of day, solar irradiance level, and the atmospheric constituents, such as water vapor, aerosol optical depth, ozone, etc.

The broadband direct beam irradiance $\left(W_{B B}\right)$ is measured by the $\mathrm{ACR}_{\mathrm{BB}}$ that was calibrated during NREL Pyrheliometer Comparison (NPC-2014) with traceability to WRR [7]. The $\mathrm{ACR}_{\mathrm{BB}}$ was self-calibrating every hour to calculate its multiplication factor based on the changing environmental conditions during the outdoor measurement (e.g. temperature, pressure, humidity, irradiance level, and spectral distribution). Details about ACR self-calibration is presented in Reda, 1996 [8]. The reference broadband shortwave irradiance $\left(W_{S W}\right)$ is then calculated as:

$$
W_{S W}=W_{B B}-W_{L W}
$$

Figure 3 shows the $W_{B B}$ and $W_{S W}$ for the four clear days; the reference $W_{S W}$ irradiance is then used to calculate the window factor for the $\mathrm{ACR}_{\mathrm{SW}}$ at each data point $\left(F_{S W}\right)$,

$$
F_{S W}=\frac{W_{S W}}{M\left(V_{t p}-V_{0}\right)}
$$

where,

- $M$ is the sensitivity reciprocal (1/Sensitivity) of the $\mathrm{ACR}_{\mathrm{SW}}\left(\mathrm{W} / \mathrm{m}^{2} / \mathrm{mV}\right)$. Similar to 


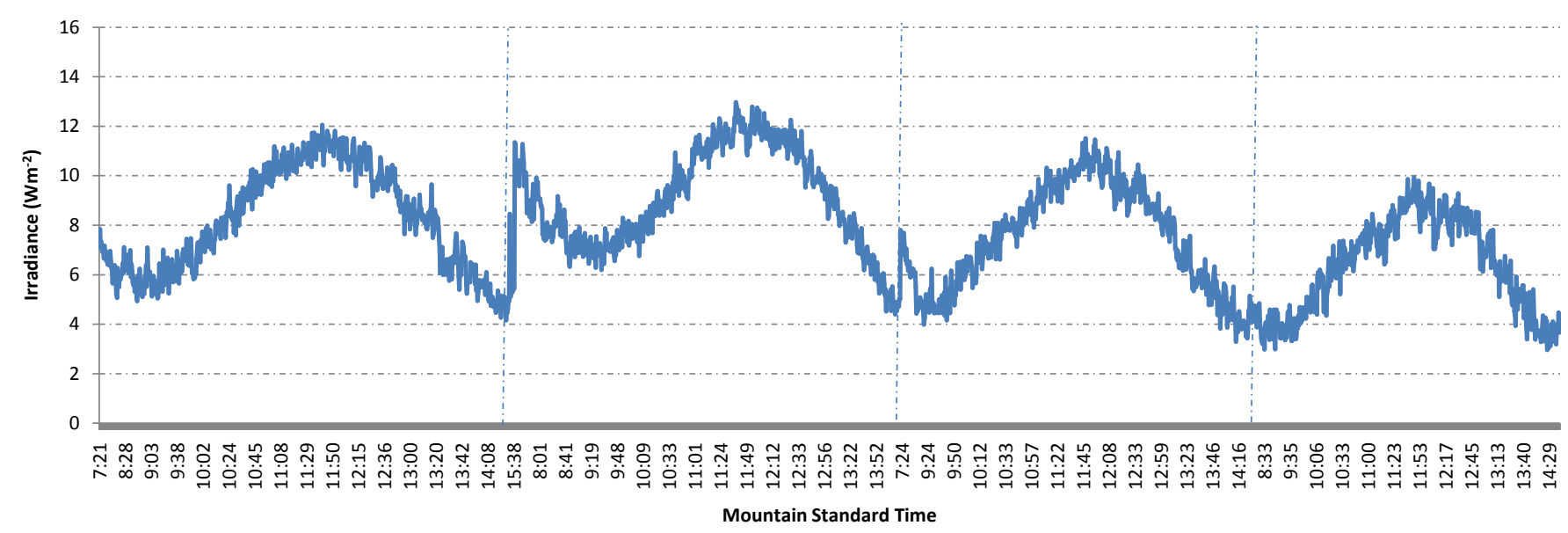

Figure 2. Reference longwave irradiance (Wsh-Wunsh) in solar beam from June 15 to June 18, 2016.

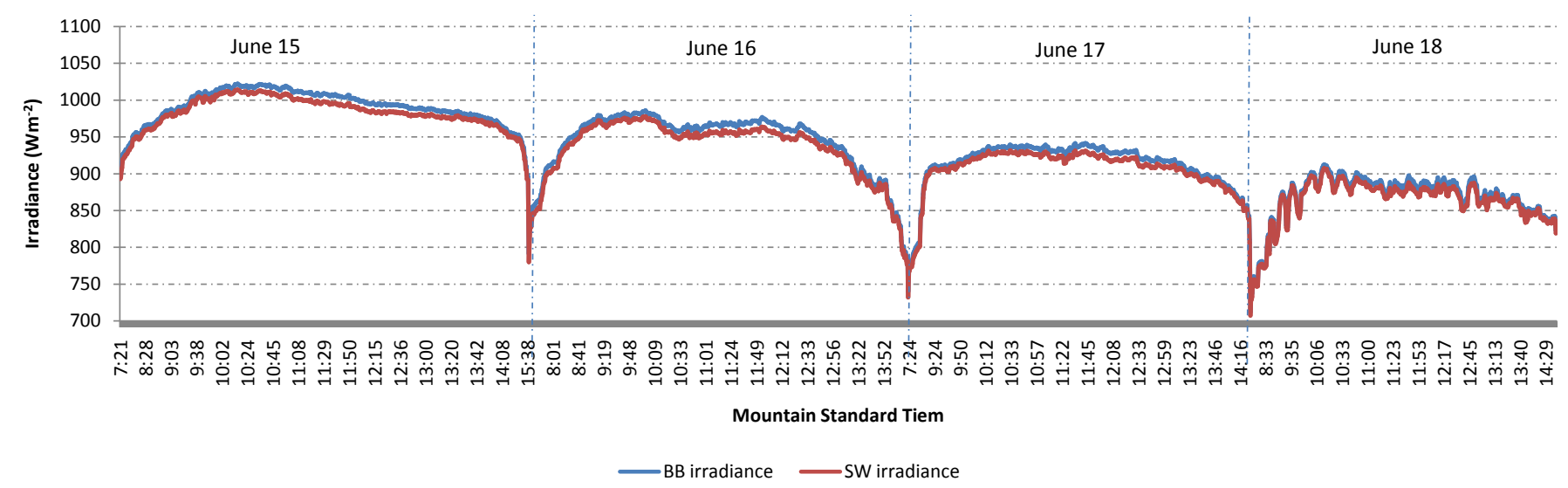

Figure 3. Broadband and shortwave irradiance from June 15 to June 18, 2016.

the $\mathrm{ACR}_{\mathrm{BB}}$ the $\mathrm{ACR}_{\mathrm{SW}}$ self-calibrates every hour to calculate $M[8]$.

- $V_{t p}$ is the thermopile output voltage when the shutter of the $\mathrm{ACR}_{\mathrm{SW}}$ is open $(\mathrm{mV})$ (i.e. the direct solar beam is incident on the thermopile's receiving junctions).

- $V_{0}$ is the thermopile output voltage when the cavity is self-calibrating and the shutter is closed [i.e. no solar irradiance $(\mathrm{mV})$ ].

Figure 4 shows the window factor, the average $F_{S W}$ and its standard deviation (SD). The uncertainty with $95 \%$ confidence level $\left(U_{95, S w}\right)$ for the $A_{C R}$ calibration is then calculated using the ISO Guide to the Expression of Uncertainty in Measurement (GUM) [9].

Table 1 shows the results of calibration and its uncertainty, where $\mathrm{u}_{95, \mathrm{BB}}$ is the standard uncertainty of $\mathrm{ACR}_{\mathrm{BB}}$ from NPC-2014 [7] and $\mathrm{u}_{95, \mathrm{LW}}$ is the standard uncertainty of $W_{L W}[6]$. From the Table, the $F_{S W}$ of the $\mathrm{ACR}_{\mathrm{SW}}$ equals 1.05655 and $\mathrm{U}_{95, \mathrm{SW}}$ equals $0.41 \%$.

\subsection{Shortwave Radiometer Calibration}

During the calibration, each measurement data point consists of simultaneous recording of the following parameters:

- Output voltage from the test radiometer, $V(\mu \mathrm{V})$.

- Reference irradiance measured by $\mathrm{ACR}_{\mathrm{BB}}$ and $\mathrm{ACR}_{\mathrm{SW}}, W_{B B}$ and $W_{S W}\left(\mathrm{~W} \cdot \mathrm{m}^{-2}\right)$. 


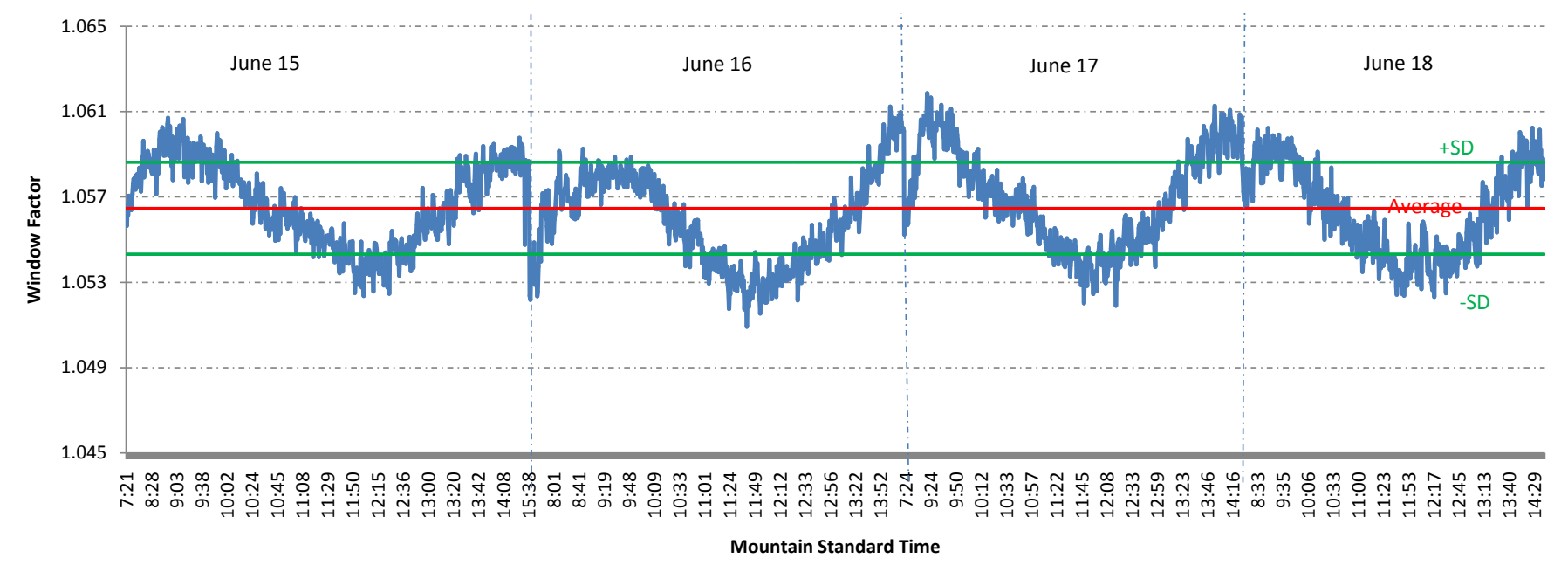

Figure 4. Window factor (FSW) for the absolute cavity radiometer with Schott glass window from June 15 to June 18, 2016.

Table 1. Calibration results of the $\mathrm{ACR}_{\mathrm{SW}}$.

\begin{tabular}{cc}
\hline Window Factor & 1.05655 \\
$\% \mathrm{SD}=$ Type A Standard Uncertainty $(\mathrm{uA})$ & 0.0002 \\
$\%$ Standard Unceratainty $\left(\mathrm{u}_{95, \mathrm{BB})}\right.$ & 0.19 \\
$\%$ Standard Unceratainty $\left(\mathrm{u}_{95, \mathrm{LW})}\right.$ & 0.21 \\
Coverage Factor & 1.96 \\
$\% \mathrm{U}_{95, \mathrm{SW}}$ & 0.41 \\
\hline
\end{tabular}

- Net longwave irradiance measured by a pyrgeometer, $W_{\text {net }}\left(\mathrm{W} \cdot \mathrm{m}^{-2}\right)$.

- Reference diffuse irradiance measured by a shaded pyranometer, $D\left(\mathrm{~W} \cdot \mathrm{m}^{-2}\right)$.

- The solar zenith angle calculated using the Solar Position Algorithm (SPA), $\Theta\left({ }^{\circ}\right)[10]$.

The responsivity of each shortwave radiometer is then calculated using two methods: Using the $A C R_{B B}$ as a reference and using the $A_{C R}$ as the reference. The following equation is used to calculate the broadband responsivity $\left(R S_{B B}\right)[11]$ :

$$
R S_{B B}=\frac{V-R_{n e t} * W_{n e t}}{W_{B B} * \cos \Theta+D}
$$

where $R_{\text {net }}$ is the pyranometer's net infrared responsivity calculated using the method described in [12], in $\mu \mathrm{V} /\left(\mathrm{W} \cdot \mathrm{m}^{-2}\right)$.

The shortwave responsivity $\left(R S_{S W}\right)$ is then calculated using Equation (4) by replacing $R S_{B B}$ and $W_{B B}$ by $R S_{S W}$ and $W_{S W}$, respectively.

\section{Results}

Figures 5-8 show the difference between the $R S_{B B}$ and $R S_{S W}$ for five radiometers, two thermopile pyrheliometers (Eppley Laboratory, Inc., model NIP and Kipp and Zonen model CHP1), two thermopile pyranometers (Eppley Laboratory, Inc., model PSP and Kipp and Zonen model CMP22), and one photodiode pyranometer (Kipp and Zonen model SP Lite2). From the figures, pyrheliometers $R S_{S W}$ is larger than $R S_{B B}$ by at least $0.75 \%$, and for pyranometers $R S_{S W}$ is larger than $R S_{B B}$ by at least $0.6 \%$. Historically, direct solar beam and global irradiance is calculated using the $R S_{B B}$ for all radiometers. 

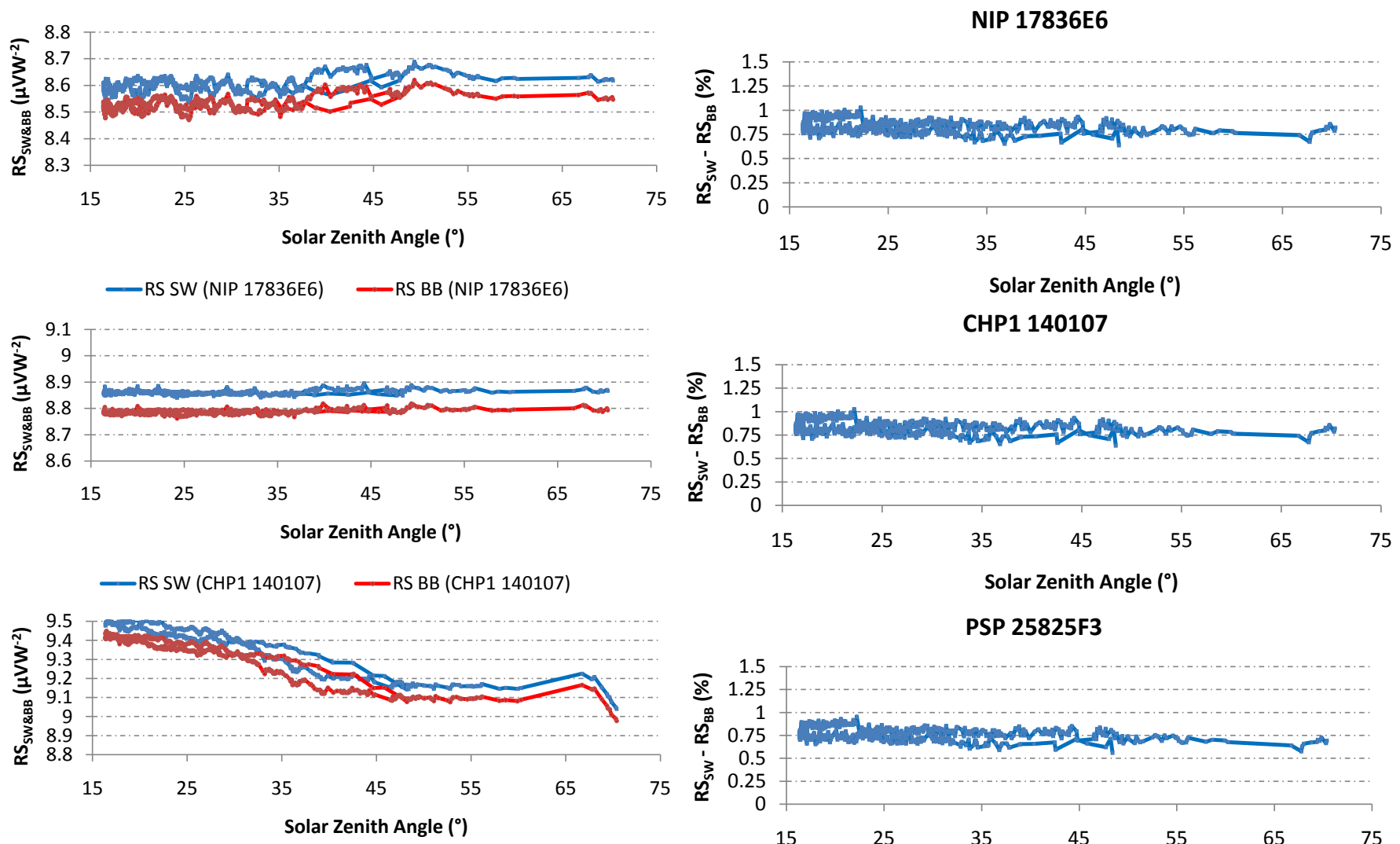

PSP 25825F3
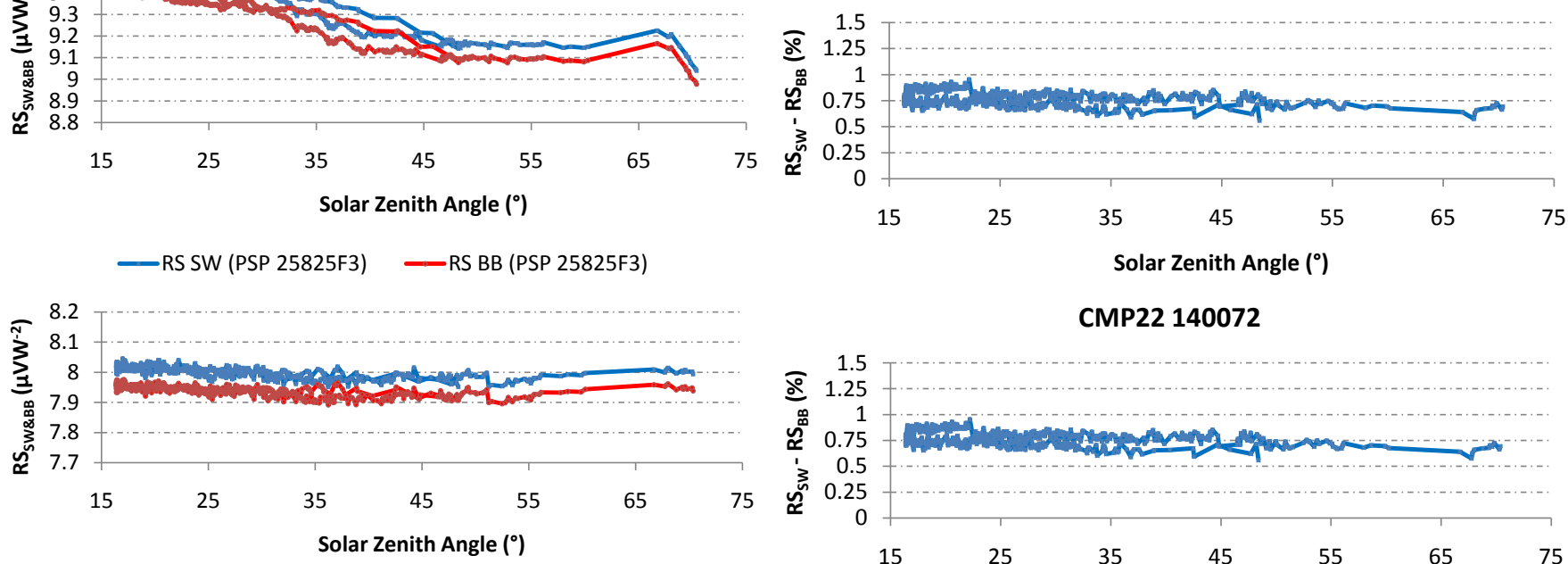

- RS SW (CMP22 140072) - RS BB (CMP22 140072)
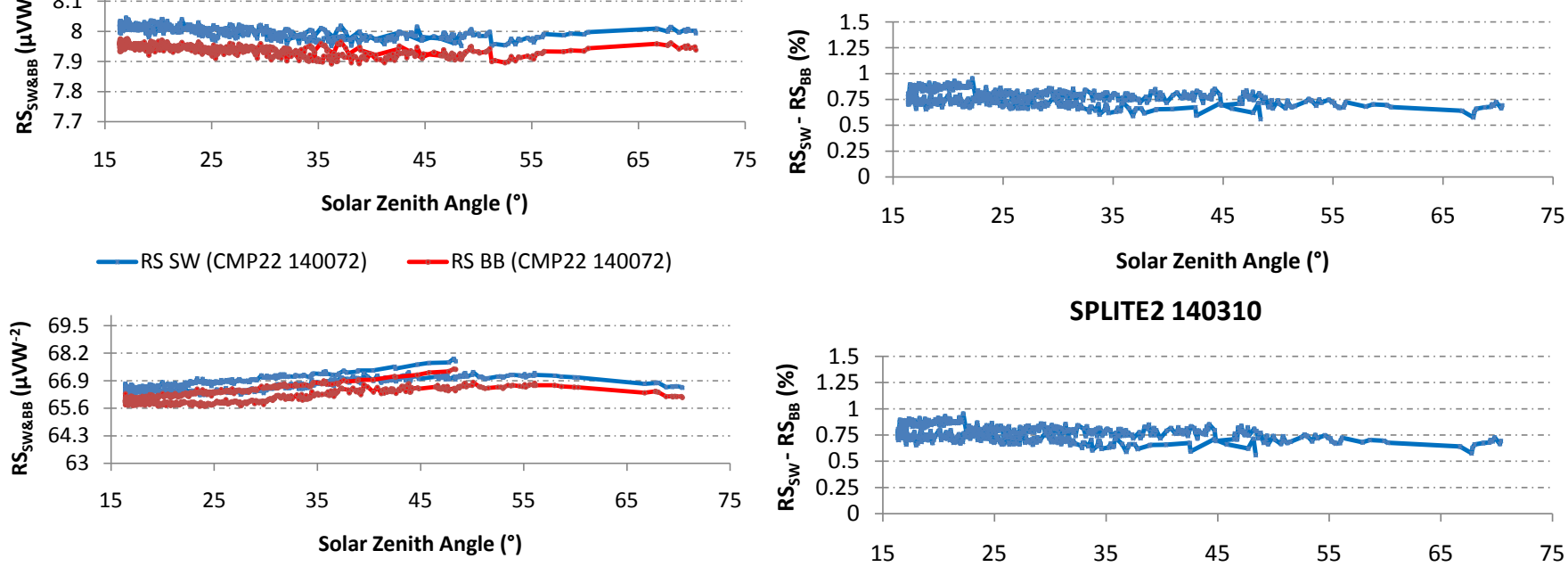

SPLITE2 140310

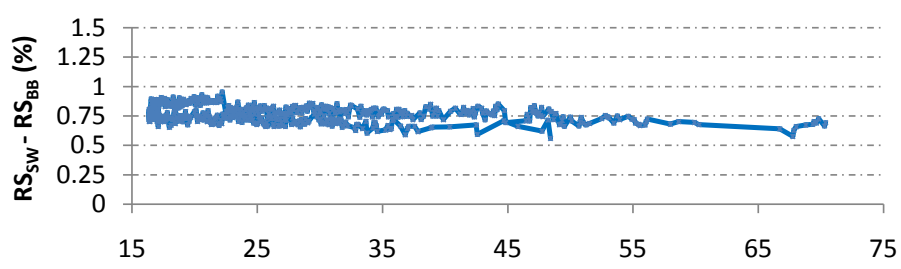

—RS SW (SPLITE2 140310) —RS BB (SPLITE2 140310)

Solar Zenith Angle ( $\left.{ }^{\circ}\right)$

Figure 5. Shortwave and broadband responsivities and percentage differences on June 15, 2016.

This implies that when the radiometers are deployed in the field after being calibrated using $\mathrm{ACR}_{\mathrm{SW}}$, the measured direct broadband shortwave beam solar irradiance might be lower than the historical irradiance by at least $0.75 \%$, and that the global broadband shortwave solar irradiance might be lower than the historical global irradiance by $0.6 \%$.

The same calibration method was repeated at the USA-Department of Energy (DOE), Atmospheric Radiation Measurement (ARM) program at the Southern Great 

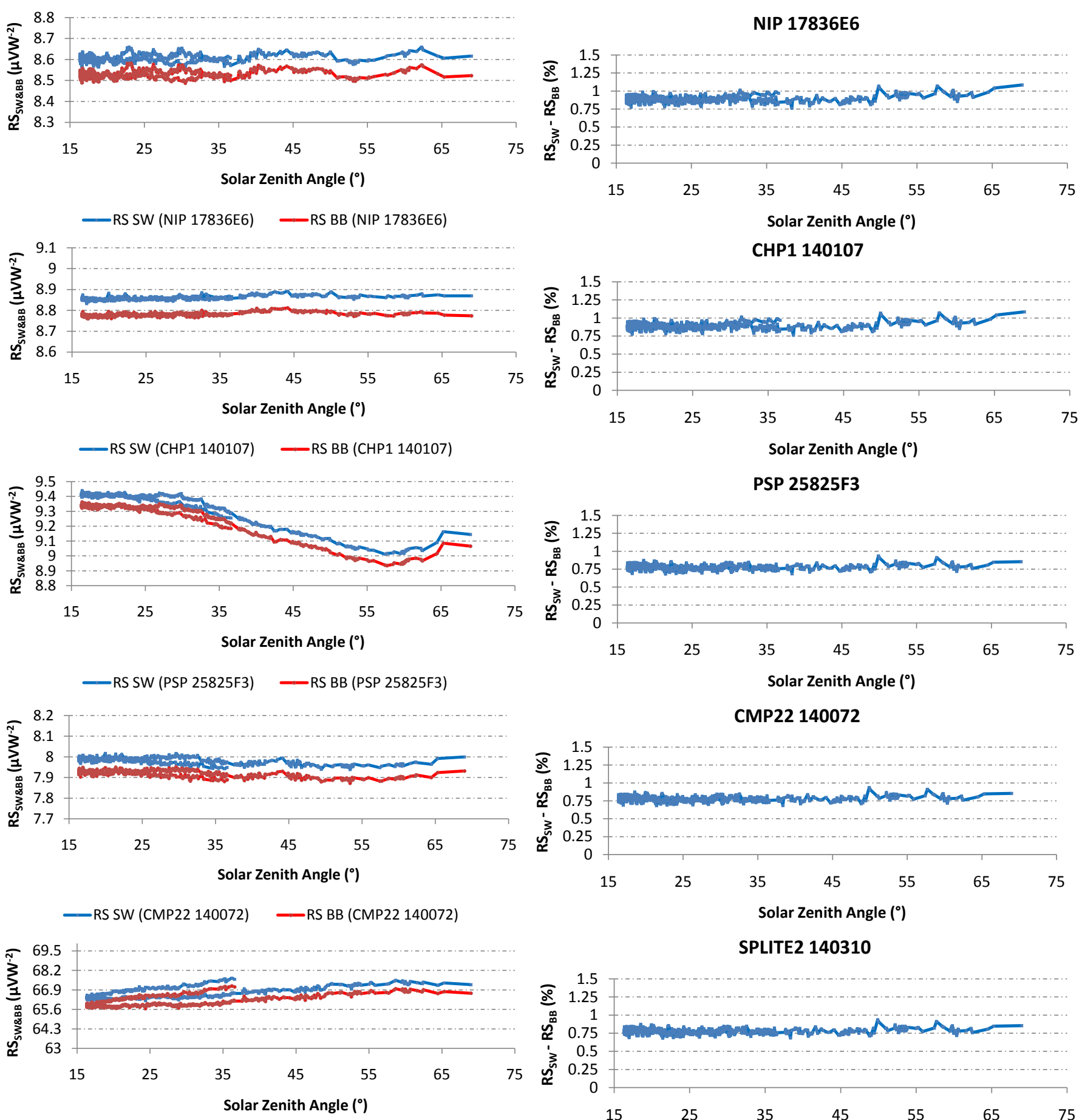

—RS SW (SPLITE2 140310) —RS BB (SPLITE2 140310)

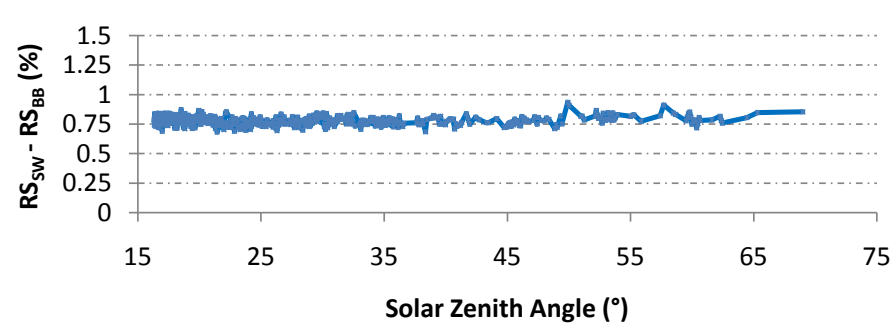

CMP22 140072

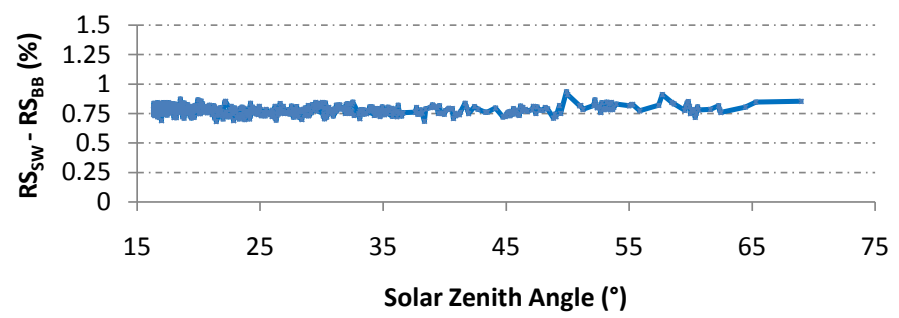

SPLITE2 140310

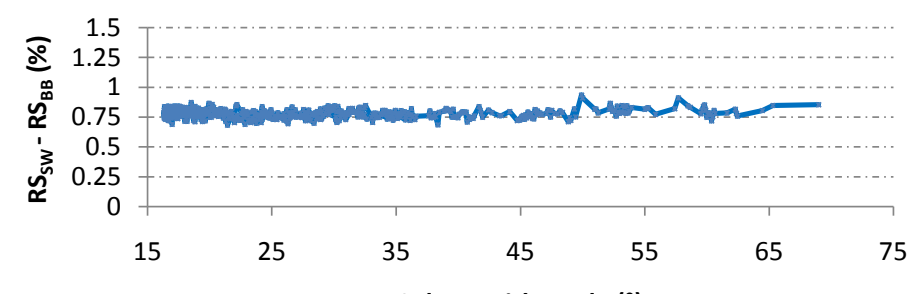

Figure 6. Shortwave and broadband responsivities and percentage differences on June 16, 2016.

Plains (SGP) site, which is at an elevation of 318 meters above sea level. Figure 9 shows the difference between the $R S_{B B}$ and $R S_{S W}$ for the same five radiometers. From the figure it is noted that for pyrheliometers $R S_{S W}$ is larger than $R S_{B B}$ by at least $1.1 \%$, and for pyranometers $R S_{S W}$ is consistently larger than $R S_{B B}$ by at least $0.9 \%$. Again, historical direct beam and global irradiance is calculated using the $R S_{B B}$ for all radiometers, which implies that when the radiometers are deployed in the field after being calibrated using 

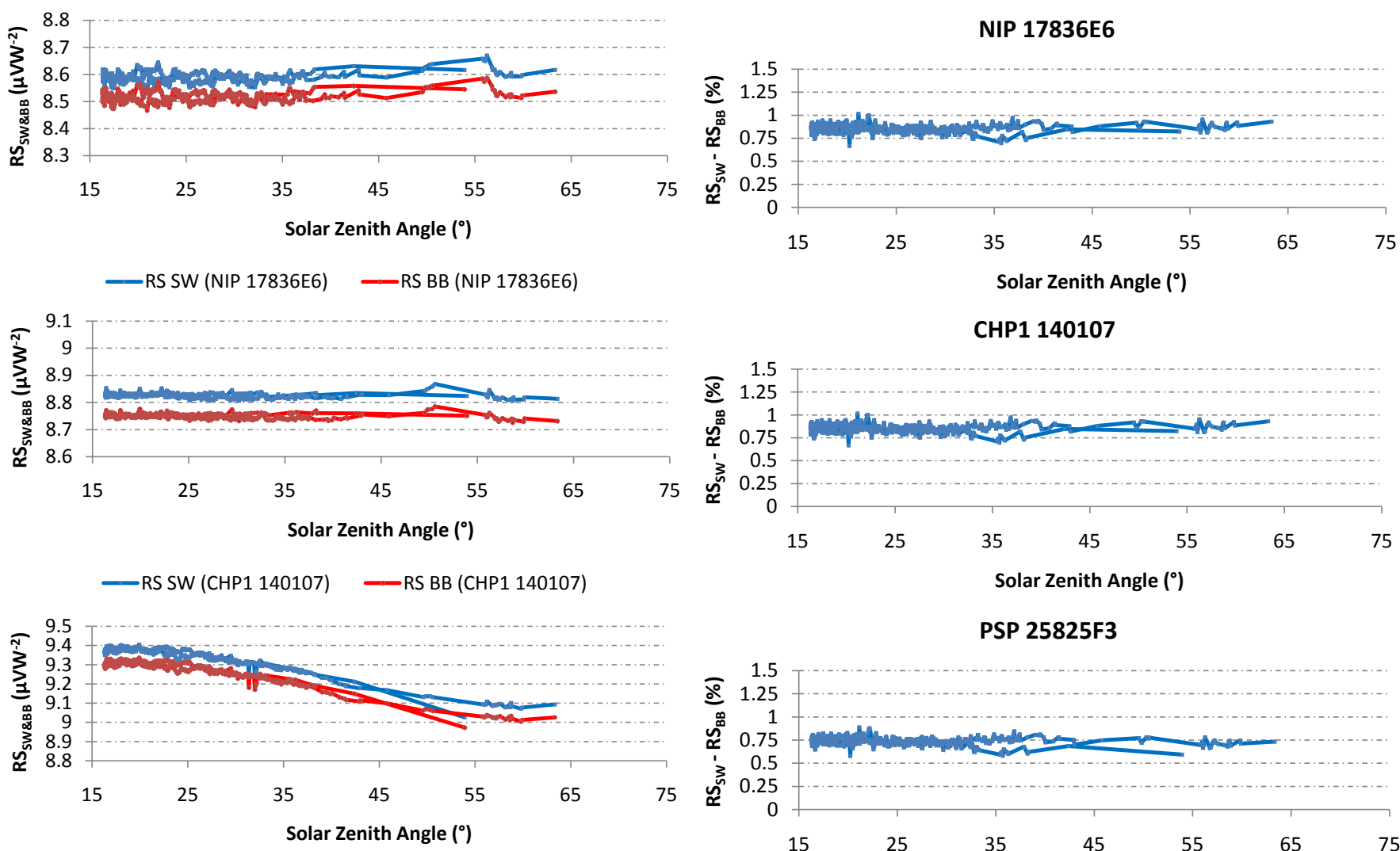

PSP 25825F3
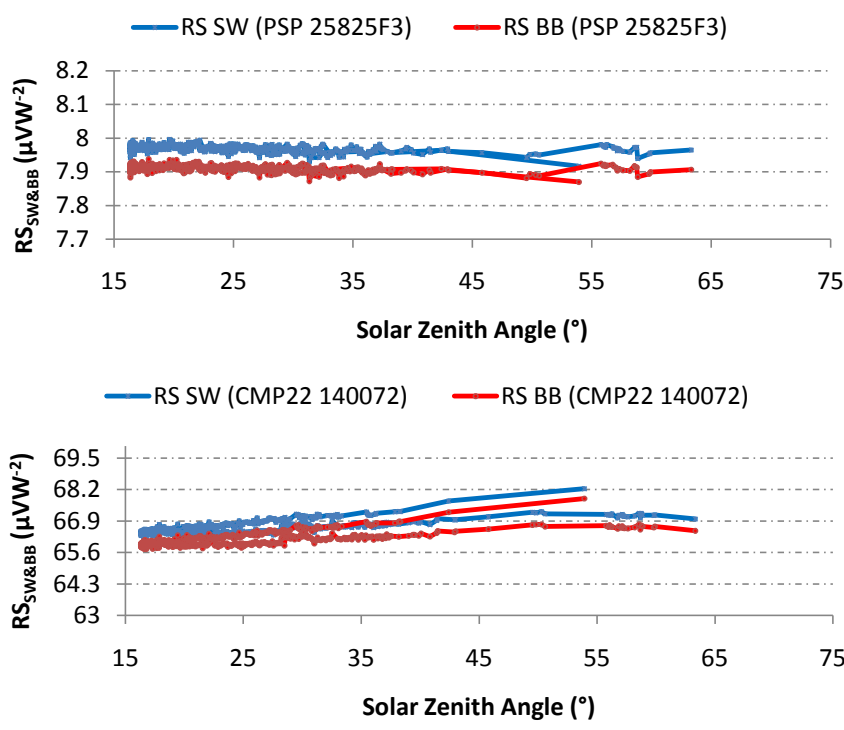

—RS SW (SPLITE2 140310) —RS BB (SPLITE2 140310)

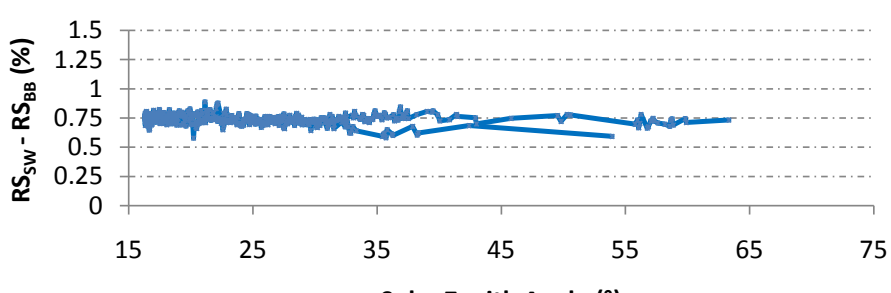

Solar Zenith Angle ( ${ }^{\circ}$ )

CMP22 140072

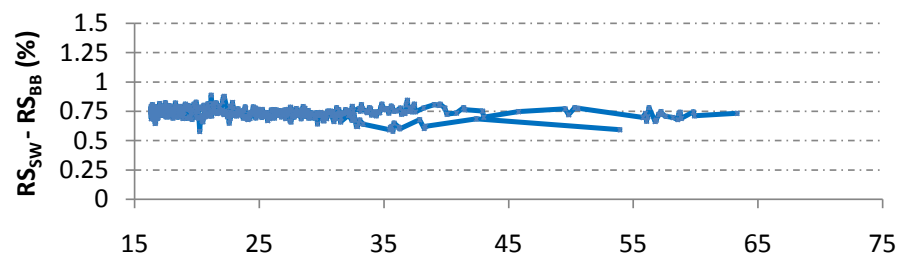

Solar Zenith Angle $\left({ }^{\circ}\right)$

SPLITE2 140310

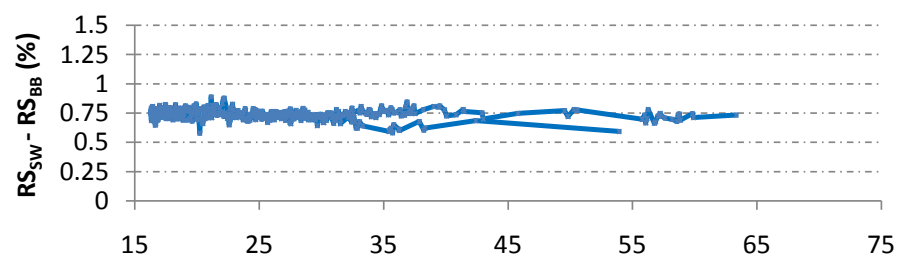

Solar Zenith Angle $\left({ }^{\circ}\right)$

Figure 7. Shortwave and broadband responsivities and percentage differences on June 17, 2016.

$\mathrm{ACR}_{\mathrm{SW}}$, the measured direct beam solar irradiance might be lower than the historical irradiance by at least $1.1 \%$, and the global solar irradiance might be lower than the historical global irradiance by $0.9 \%$.

\section{Conclusion}

We find that by using the historical calibration method of broadband shortwave radi- 

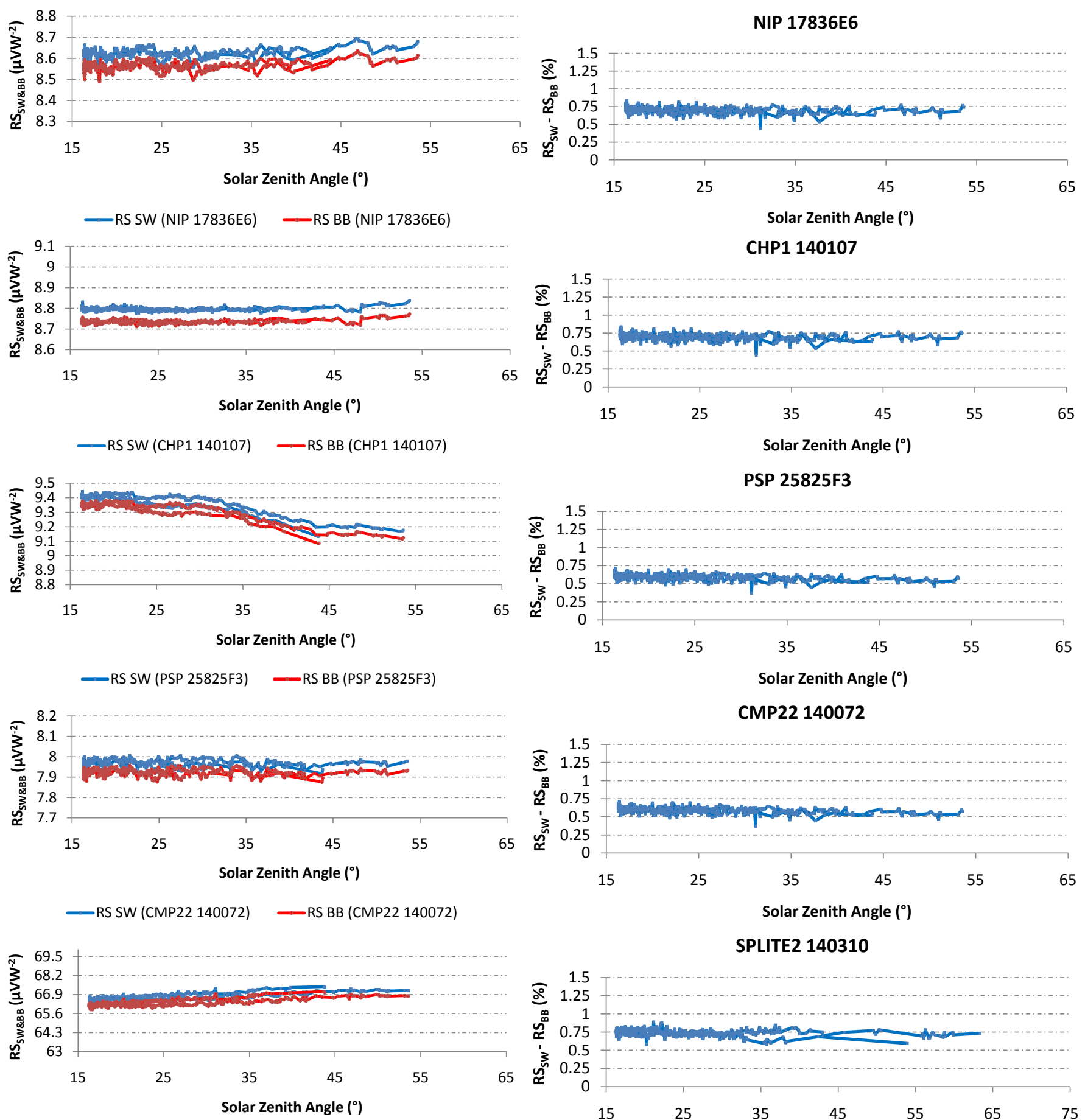

—RS SW (SPLITE2 140310) —RS BB (SPLITE2 140310)
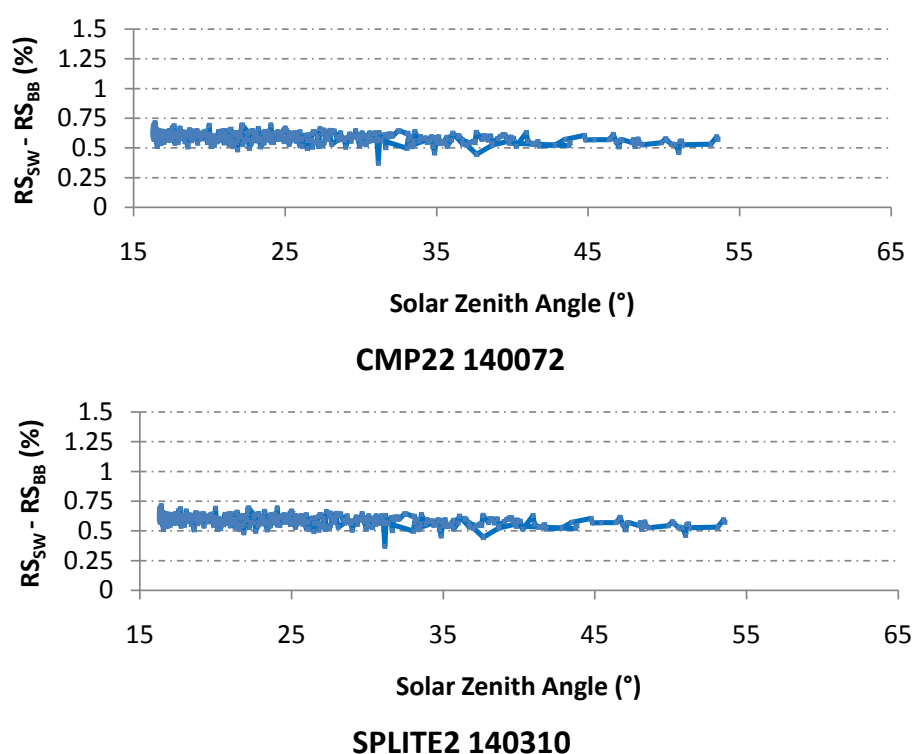

Figure 8. Shortwave and broadband responsivities and percentage differences on June 18, 2016.

ometers recommended by ISO 9059:1990 results in an overestimation in the field measurement of the direct broadband shortwave beam solar irradiance by at least $0.75 \%$ and the global broadband shortwave solar irradiance by at least $0.6 \%$. This overestimation might exceed $1 \%$ based on the atmospheric conditions during the calibration, primarily water vapor and aerosols. Since shortwave radiometers are designed to measure the broadband shortwave solar irradiance in the spectral range from $0.3 \mu \mathrm{m}$ to $3 \mu \mathrm{m}$, 

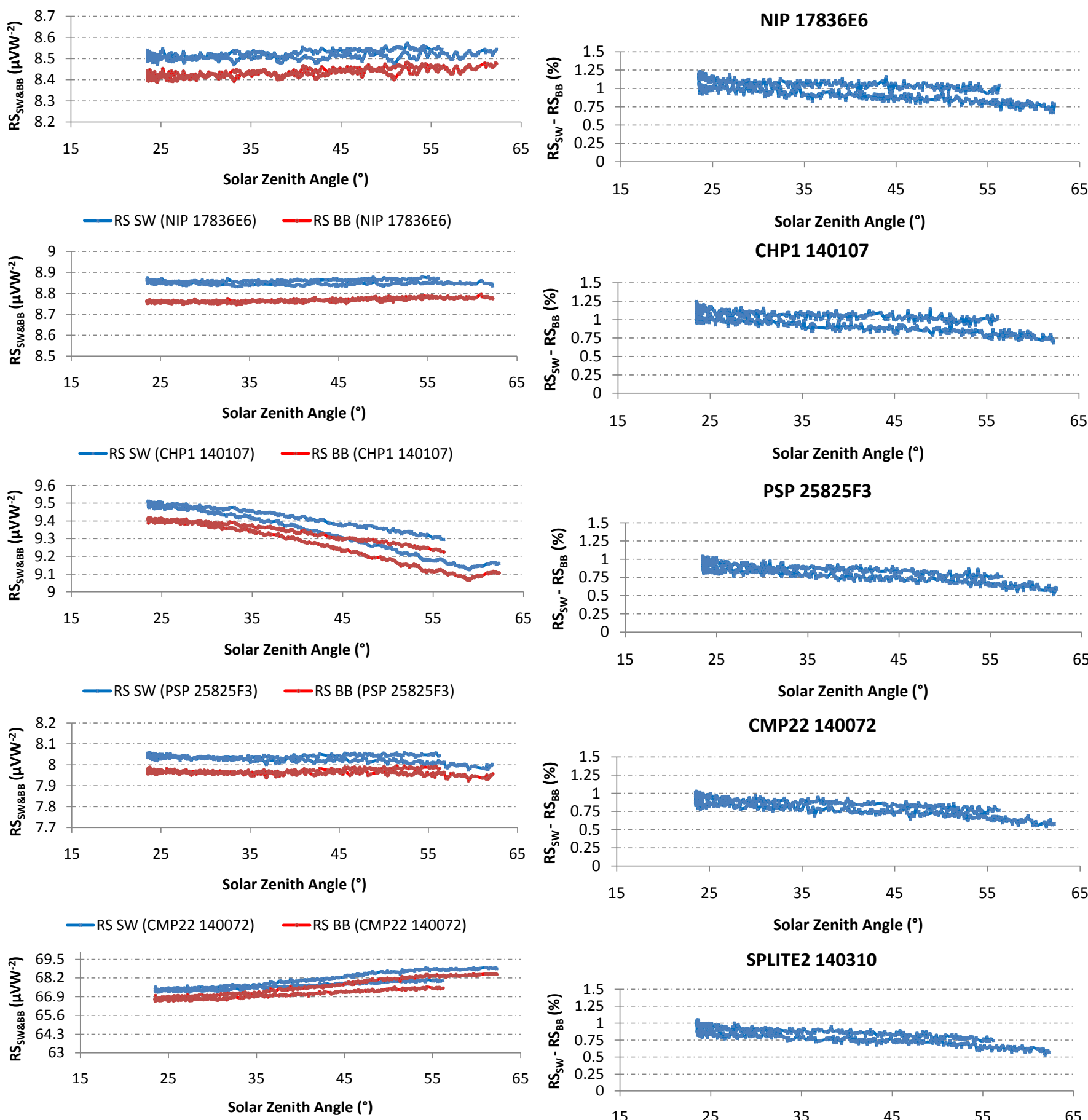

-RS SW (SPLIT2 140310) -RS BB (SPLIT2 140310)

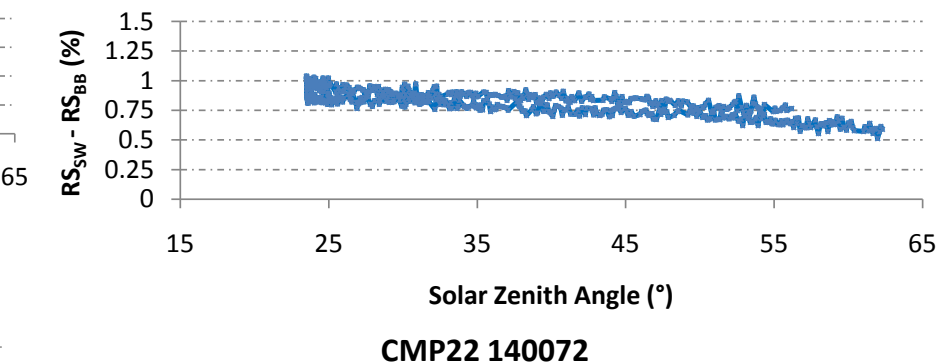

Figure 9. Shortwave and broadband responsivities and percentage differences at SGP on August 17, 2016.

per ISO 9060:1990, the recommended calibration method by ISO 9059-1990 would result in biases in the calibration results. These biases might be significant in atmospheric science and solar energy applications.

\section{Discussion}

While most users of such radiometers are interested in measuring the broadband short- 
wave irradiance, some users are interested in measuring the broadband solar irradiance $\left(W_{B B}\right)$. For the latter, it is recommended that radiometers be designed with domes or windows that transmit the broadband spectral range to avoid such calibration discrepancy. The purpose of this article is to raise the awareness of the calibration discrepancy to the users of such radiometers, and open a discussion within the solar and atmospheric science community to define their expectation from such radiometers to the radiometers' manufacturers and calibration providers.

\section{Acknowledgements}

We would like to thank NREL's solar program staff, NREL's Quality Management Systems and Assurance Office, NREL Metrology Laboratory, and DOE-Atmospheric Radiation Measurement (ARM) program for providing the funds for this publication. We extend special appreciation to Martina Newman for providing the superb administrative support by taking care of all the logistics associated with this effort.

\section{References}

[1] ISO 9059:1990. Solar Energy-Calibration of Field Pyrheliometers by Comparison to a Reference Pyrheliometer. International Organization for Standardization, Geneva, 8 p.

[2] Müllejans, H., Zaaiman, W., Merli, F., Dunlop, E.D. and Ossenbrink, H.A. (2015) Comparison of Traceable Calibration Methods for Primary Photovoltaic Reference Cells. Journal of Progress in Photovoltaics: Research and Applications, 13, 661-671. https://doi.org/10.1002/pip.625

[3] WRC/PMOD (2015) International Pyrheliometer Comparison, IPC-XII. Davos, 28 September-16 October 2015, WMO IOM Report No. 124.

[4] Beaubien, D.J., Bisberg, A. and Beaubien, A.F. (1997) Investigations in Pyranometer Design. Journal of Atmospheric and Oceanic Technology, 15, 677-686.

[5] ISO 9060:1990. Solar Energy-Specification and Classification of Instruments for Measuring Hemispherical Solar and Direct Solar Radiation. International Organization for Standardization, Geneva, 11 p.

[6] Reda, I., Konings, J. and Xie, Y. (2015) Method to Measure the Broadband Longwave Irradiance in the Terrestrial Direct Solar Beam. Journal of Atmospheric and Solar-Terrestrial Physics, 129, 23-29. https://doi.org/10.1016/j.jastp.2015.04.003

[7] Reda, I., Dooraghi, M. and Habte, A. (2014) NREL Pyrheliometer Comparisons. 22-26 September 2014, NREL/TP-3B10-63050. https://doi.org/10.2172/1160195

[8] Reda, I. (1996) Calibration of a Solar Absolute Cavity Radiometer with Traceability to the World Radiometric Reference. NREL/TP-463-20619. https://doi.org/10.2172/15000940

[9] Joint Committee for Guides in Metrology Working Group 1, Guide to the Expression of Uncertainty in Measurement, 2008. http://www.bipm.org/utils/common/documents/jcgm/JCGM_100_2008_E.pdf

[10] Reda, I. and Andreas, A. (2004) Solar Position Algorithm for Solar Radiation Applications. Journal of Solar Energy, 76, 577-589. https://doi.org/10.1016/j.solener.2003.12.003

[11] Reda, I., Myers, M. and Stoffel, T. (2008) Uncertainty Estimate for the Outdoor Calibration of Solar Pyranometers: A Metrologist Perspective. Journal of Measurement Science, Measure, 3, 58-66.

[12] Reda, I., Hickey, J., Long, C., Myers, D., Stoffel, T., Wilcox, S., Michalsky, J.J., Dutton, E.G. and Nelson, D. (2005) Using a Blackbody to Calculate Net Infrared Responsivity of Short- 
wave Solar Pyranometers to Correct for Their Thermal Offset Error during Outdoor Calibration Using the Component Sum Method. Journal of Atmospheric and Oceanic Technology, 22, 1531-1540. https://doi.org/10.1175/JTECH1782.1

Submit or recommend next manuscript to SCIRP and we will provide best service for you:

Accepting pre-submission inquiries through Email, Facebook, LinkedIn, Twitter, etc. A wide selection of journals (inclusive of 9 subjects, more than 200 journals) Providing 24-hour high-quality service User-friendly online submission system Fair and swift peer-review system Efficient typesetting and proofreading procedure Display of the result of downloads and visits, as well as the number of cited articles Maximum dissemination of your research work

Submit your manuscript at: http://papersubmission.scirp.org/ Or contact acs@scirp.org 